\title{
68Ga-FAPI improves tumor staging in patients with colorectal cancer: comparing to 18F-FDG PET/CT
}

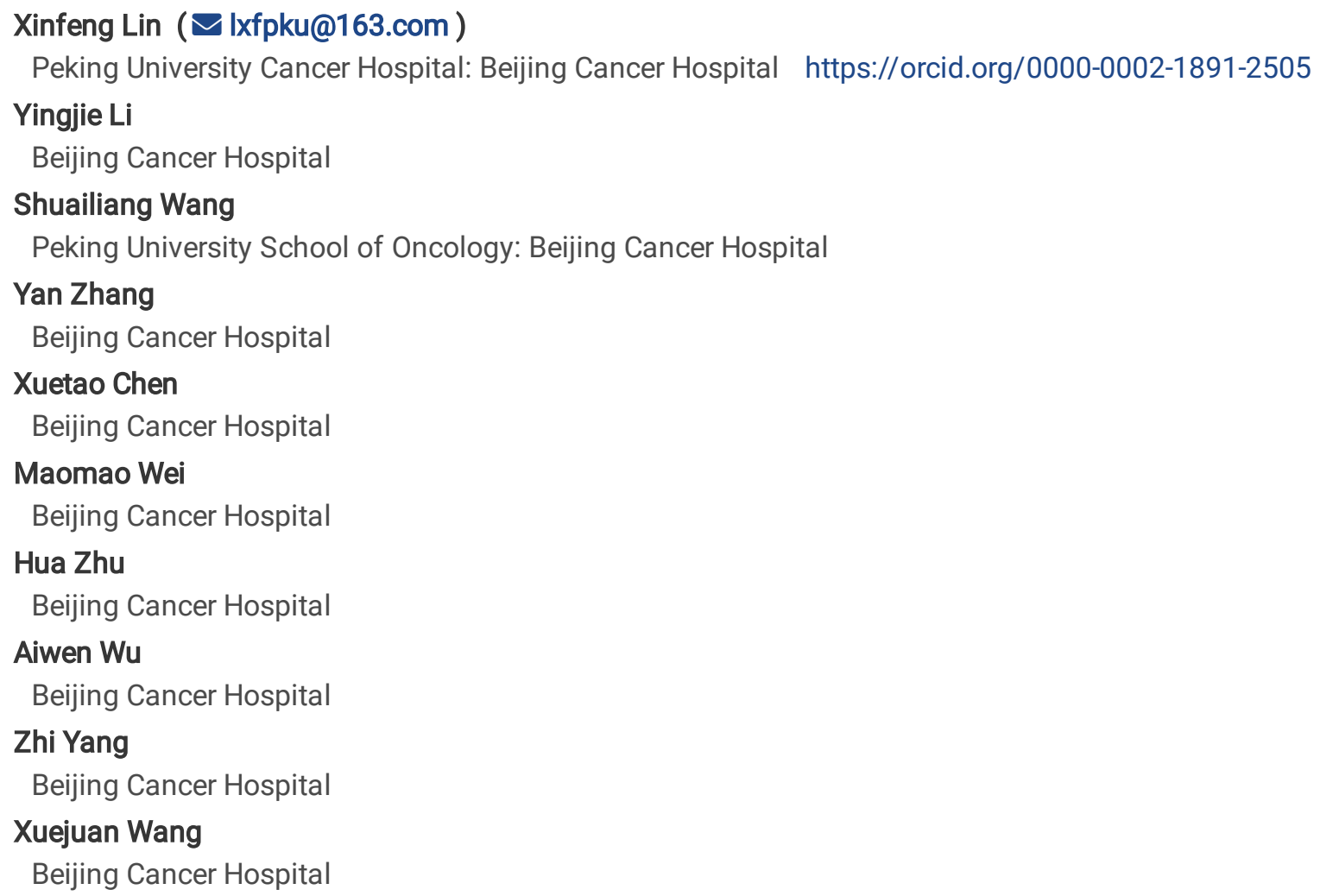

\section{Research Article}

Keywords: FAPI, colorectal cancer, fibroblast-activation protein, inhibitor, positron emission tomography

Posted Date: January 31st, 2022

DOI: https://doi.org/10.21203/rs.3.rs-1293831/v1

License: (1) (1) This work is licensed under a Creative Commons Attribution 4.0 International License. Read Full License 


\section{Abstract \\ Purpose}

Gallium-68 $\left({ }^{68} \mathrm{Ga}\right)$-labeled fibroblast-activation protein inhibitor (FAPI) is a novel tracer that binds fibroblast-activation protein (FAP), which is overexpressed in colorectal cancers with a prominent stroma including cancer-associated fibroblasts (CAFs). The present study aimed to compare the diagnostic performance of ${ }^{68} \mathrm{Ga}-\mathrm{FAPI}$ positron emission tomography (PET)/computed tomography (CT) with that of fluorine-18 $\left({ }^{18} \mathrm{~F}\right)$-fluorodeoxyglucose (FDG) PET/CT in primary and metastatic colorectal cancer lesions.

\section{Methods}

This prospective study included the image analyses of 37 patients with colorectal cancer who were sequentially evaluated using $\mathrm{PET} / \mathrm{CT}$ with ${ }^{18} \mathrm{~F}-\mathrm{FDG}$ and ${ }^{68} \mathrm{Ga}-\mathrm{FAPI}$. Tracer uptakes were compared using Wilcoxon's signed-rank test.

\section{Results}

The cohort comprised 37 patients, including 18 treatment-naïve patients and 19 post-treatment patients. In primary colorectal cancer lesions, the average ${ }^{68} \mathrm{Ga}$-FAPI and ${ }^{18} \mathrm{~F}-\mathrm{FDG}$ maximum standardized uptake values (SUV $\max$ ) were $12.5 \pm 4.8$ and $13.2 \pm$ $5.7(P=0.38)$, respectively, in the treatment-naïve group and $6.0 \pm 4.3$ and $7.9 \pm 7.2$, respectively, in the neoadjuvant chemotherapy group $(P=0.09)$; the detection rate was $100 \%$ with both tracers $(18 / 18)$. The $S U V_{\text {max }}$ value of ${ }^{68} \mathrm{Ga}$-FAPI in signet-ring/mucinous carcinomas $(12.3 \pm 5.2)$ was higher than that of ${ }^{18} \mathrm{~F}-\mathrm{FDG}(8.3 \pm 4.0)(P=0.03)$. In addition, the average ${ }^{68} \mathrm{Ga}-\mathrm{FAPI}$ uptake was lower than that of ${ }^{18} \mathrm{~F}$-FDG in poorly differentiated carcinomas $(12.7 \pm 3.7$ vs. $18.1 \pm 4.1, P=0.04)$. Compared with ${ }^{18} \mathrm{~F}-\mathrm{FDG}$ $\mathrm{PET} / \mathrm{CT}$, clinical TNM staging based on ${ }^{68} \mathrm{Ga}-\mathrm{FAPI}$ PET/CT led to upstaging in 6 patients $(16.2 \%)$ and downstaging in 3 patients (8.1\%). In peritoneal and liver metastases, both the $\mathrm{SUV}_{\max }$ and the target/background ratio were higher with ${ }^{68} \mathrm{Ga}-\mathrm{FAPI}$ compared to ${ }^{18}$ F-FDG (3.7 vs. $2.6, P=0.02$, and 6.5 vs. $0.89, P=0.01$, respectively).

\section{Conclusion}

As a novel PET/CT tracer, ${ }^{68} \mathrm{Ga}-\mathrm{FAPI}$ showed its advantage in the detection of lymph nodes, and distant metastases, which improved staging of CRC.

\section{Introduction}

Colorectal cancer (CRC) was the fifth most common cause of cancer-related deaths in the United States in 2020 [1]. At diagnosis, $22 \%$ of patients with CRC have metastases whereas $50 \%$ of patients develop metastases during their lifetime [2, 3]. Optimal imaging for $\mathrm{CRC}$ is crucial for accurate initial staging and selection of primary therapy as well as during follow-up examinations for accurate and timely detection of local recurrence and/or metastatic spread.

Noninvasive molecular imaging with novel PET tracers is increasingly being deployed in clinical oncology. Fluorine-18 $\left({ }^{18} \mathrm{~F}\right)$ fluorodeoxyglucose (FDG) PET/CT, which utilizes altered glucose metabolism in cancer cells, is a valuable imaging modality for the management of CRC $[4,5]$. However, ${ }^{18} \mathrm{~F}$-FDG has several limitations such as low specificity, inability to detect small-volume lesions, and lack of isotope uptake in mucinous and signet-ring cell carcinomas [6, 7]. Imaging of the tumor microenvironment beyond the detection of tumor metabolism is a new approach to elucidate in vivo tumor biology with potential translational implications in clinical oncology. Fibroblast-activation protein (FAP) is a membrane-anchored peptidase that is highly expressed in cancer-associated fibroblasts (CAFs) in more than $90 \%$ of epithelial tumors, including CRC, and contributes to the progression and worse prognosis in a variety of cancers [8-11]. Several recently developed quinolone-based FAP inhibitors (FAPIs) coupled to chelators, including gallium-68 $\left({ }^{68} \mathrm{Ga}\right)$ - FAPI, have been demonstrated to provide advantages in staging and restaging compared 
with ${ }^{18}$ F-FDG PET/CT in a spectrum of cancers including peritonitis carcinomatosis [9-11]. Koerber et al. [12] and Pang et al. [13] reported the avidity of ${ }^{68} \mathrm{Ga}$-FAPI in PET/CT imaging of CRC, supporting the potential utility of FAP-targeted imaging in advanced CRC. Thus, we assessed the avidity of ${ }^{68} \mathrm{Ga}$-FAPI in CRC to compare the clinical impact of ${ }^{68} \mathrm{Ga}$-FAPI PET/CT on TNM staging to that of standard-of-care ${ }^{18} \mathrm{~F}-\mathrm{FDG} \mathrm{PET} / \mathrm{CT}$ imaging in patients with primary and recurrent/metastatic CRC.

\section{Materials And Methods}

\section{Patients}

This prospective study was approved by the Institutional Review Board of the study institution (no. 2019KT95) and registered in ClinicalTrials.gov (NCT04750772). Written informed consent was obtained from all patients who were recruited for study enrolment in the study institution. The inclusion criteria were as follows: age > 18 years, histologically confirmed CRC, patient referral to the Nuclear Medicine Department for both ${ }^{18} \mathrm{~F}-\mathrm{FDG}$ and ${ }^{68} \mathrm{Ga}$-FAPI PET/CT scans for the purpose of staging or restaging aiding to optimize clinical decision making and written informed consent for study participation. Pregnant or lactating female patients and severe liver or kidney dysfunction were excluded from the study. The final study cohort comprised $37 \mathrm{CRC}$ patients. The study flowchart of patient enrolment is presented in Online Resource 1.

\section{Synthesis of ${ }^{18} \mathrm{~F}-\mathrm{FDG}$ and ${ }^{68} \mathrm{Ga}-\mathrm{FAPI}$}

${ }^{18} \mathrm{~F}-\mathrm{FDG}$ was manufactured in accordance with the standard method described by our laboratory using the coincidence ${ }^{18} \mathrm{~F}-\mathrm{FDG}$ synthesis module. Synthesis and radiolabeling of ${ }^{68} \mathrm{Ga}$-FAPI-04 were performed as previously described [14]. The radiochemical purity exceeded $95 \%$ for both ${ }^{18} \mathrm{~F}-\mathrm{FDG}$ and ${ }^{68} \mathrm{Ga}-\mathrm{FAPI}-04$. The final products underwent sterility testing before administration via intravenous injection.

\section{PET/CT imaging}

All enrolled patients underwent routine ${ }^{18} \mathrm{~F}-\mathrm{FDG} \mathrm{PET} / \mathrm{CT}$ and subsequent ${ }^{68} \mathrm{Ga}-\mathrm{FAPI} \mathrm{PET} / \mathrm{CT}$ within one week. All patients fasted for at least six hours before ${ }^{18} \mathrm{~F}-\mathrm{FDG} \mathrm{PET} / \mathrm{CT}$, and a blood glucose level of $<10 \mathrm{mmol} / \mathrm{L}$ was confirmed before tracer injection. In contrast, patients with a normal diet were intravenously injected $1.85-2.96 \mathrm{MBq} / \mathrm{kg}{ }^{68} \mathrm{Ga}-\mathrm{FAPI}$ and then underwent imaging using a hybrid PET/CT scanner (Biograph mCT Flow 64; Siemens Medical Solutions USA, Knoxville/ Tennessee) approximately one hour later. Acquisition was commenced in 6-8 bed positions $(1 \mathrm{~min} / \mathrm{bed})$ that covered the area between the top of the skull and upper thigh. Non-contrast enhanced CT was performed using 100-mA modulation at $120 \mathrm{kV}$ with a slice thickness of $3 \mathrm{~mm}$ for attenuation correction and anatomical localization. All data were transferred to the Syngo MultiModality Workplace (version VE40F; Siemens Healthcare) and reconstructed to create display images of coronal, axial, and sagittal planes.

\section{Image analysis}

All images were blinded reviewed by two groups of physicians with 10-year experience in nuclear medicine and radiology. All changes and different opinions were interpreted in consensus.

Visual assessment was used, and the positive uptake was defined as focal tracer uptake higher than the background. Circular volumes of interest inside tumor lesions and healthy tissues were used to quantify radiotracer biodistribution. Tracer uptake was quantified using maximum standardized uptake value $\left(\mathrm{SUV}_{\mathrm{max}}\right)$. Primary lesions, lymph nodes, and distant metastases were respectively analyzed. The lymph nodes were classified into three groups according to the location: cervical-supraclavicular, thoracic, and abdominal/pelvic.

Tumour-node-metastasis (TNM) classification was used based on the NCCN guidelines $[15,16]$. In all patients, change in TNM stage, localization of metastases, and oncologic or radiooncologic management were recorded. The histopathologic or conventional imaging were used as the references.

\section{Statistical analysis}


All statistical analyses were performed using SPSS 23.0 (IBM, Armonk, NY, USA). The uptakes of positive lesions in ${ }^{18}$ F-FDG and ${ }^{68} \mathrm{Ga}$-FAPI PET/CT were compared using Wilcoxon's signed-rank test. A two-tailed $P$ value of $<0.05$ was considered to indicate statistically significant differences.

\section{Results}

\section{Patient characteristics}

The clinical characteristics of 37 patients enrolled in the study are summarized in Table 1. Briefly, the median cohort age was 64 (range, 33-87) years, and 23 patients (62.2\%) were male. The primary tumor was localized in colon in 13 patients (35.1\%). The most common histologic grade was moderate differentiation in $62.2 \%$ of the patients, and $4(10.8 \%)$ and 4 patients $(10.8 \%)$ had mucinous/signet-ring cell carcinoma and adenocarcinoma with a mucinous component, respectively. Finally, 18 (48.7\%) patients underwent PET/CT imaging for initial assessment and staging whereas the remaining 19 patients (51.3\%) underwent PET/CT for restaging or therapeutic evaluation.

Table 1

Patients' characteristics

\begin{tabular}{|ll|}
\hline Characteristic & Value \\
\hline No. of patients ( $\mathrm{n})$ & 37 \\
\hline Age, median (range) & 64 (33-87) \\
\hline Sex (male:female) & $23: 14$ \\
\hline Colon cancer & 13 (35.1\%) \\
\hline Rectal cancer & 24 (64.9\%) \\
\hline Treatment status & \\
\hline Treatment-naive & 18 \\
\hline Neoadjuvant treatment & 12 \\
\hline Chemotherapy/radiotherapy after surgery & 7 \\
\hline Pathology & \\
\hline Adenocarcinoma (poorly differentiated) & 5 \\
\hline Adenocarcinoma (moderately differentiated) & 23 \\
\hline Adenocarcinoma (well-differentiated) & 1 \\
\hline Mucinous/signet-ring cell carcinoma & 4 \\
\hline Adenocarcinoma with mucinous component & 4 \\
\hline Purpose of PET/CT & 18 \\
\hline Staging & 19 \\
\hline Restaging/therapeutic evaluation & \\
\hline
\end{tabular}

\section{Safety}

All patients tolerated ${ }^{68} \mathrm{Ga}$-FAPI PET-CT without any complications. No signs of drug-related side effects were reported during the entire observation period of $>5$ hours.

Distribution 
The SUV $\mathrm{max}_{\max }$ was determined for normal tissues/organs and primary tumors, after ${ }^{68} \mathrm{Ga}$-FAPI and ${ }^{18} \mathrm{~F}-\mathrm{FDG} \mathrm{PET} / \mathrm{CT}$ which were sequentially performed in all enrolled patients. The ${ }^{68} \mathrm{Ga}$-FAPI activity was significantly lower than that of ${ }^{18} \mathrm{~F}-\mathrm{FDG}$ in several normal organs $\left(P<0.001\right.$ for several), especially brain (SUV max $_{1} 0.3 \pm 0.2$ vs. $\left.9.6 \pm 2.2, P<0.001\right)$ and liver (SUV max $1.4 \pm 0.4$ vs. $3.1 \pm 0.5, P<0.001)$, leading to significantly high tumor-to-background ratios of $>2$ at both sites $(P<0.001)$. The ${ }^{68} \mathrm{Ga}-\mathrm{FAPI}$ uptake was slightly higher than that of ${ }^{18} \mathrm{~F}-\mathrm{FDG}$ in salivary and thyroid glands and the pancreas $(P<0.001$ for all). The detailed distribution of ${ }^{18} \mathrm{~F}-\mathrm{FDG}$ and ${ }^{68} \mathrm{Ga}-\mathrm{FAPI}$ uptakes is presented in Fig. 1.

\section{Primary tumors}

The histopathological data of the primary tumor were available for all treatment-naïve patients $(n=18)$ and those who received neoadjuvant chemotherapy $(n=12)$. One of these 30 patients had two primary lesions. Therefore, a total of 31 primary lesions were measured. The sensitivity was $100 \%$ (31 of 31) with both ${ }^{68} \mathrm{Ga}$-FAPI and ${ }^{18} \mathrm{~F}-\mathrm{FDG}$ PET/CT. The average SUV $\max$ and median $\mathrm{SUV}_{\max }$ (range) of primary lesions with ${ }^{68} \mathrm{Ga}-\mathrm{FAPI}$ and ${ }^{18} \mathrm{~F}$-FDG PET/CT were $10.0 \pm 5.6$ and $11.1 \pm 6.7,9.7(2.0-25.5)$ and 10.4 (2.4-25.7), respectively $(P=0.11)$. The average SUV $_{\max }$ values of ${ }^{68} \mathrm{Ga}-\mathrm{FAPI}$ and ${ }^{18} \mathrm{~F}$-FDG PET were $12.5 \pm 4.8$ vs. $13.2 \pm 5.7$, respectively, in the treatment-naïve group and $6.0 \pm 4.3$ vs.7.9 \pm 7.2 , respectively, in the neoadjuvant chemotherapy group $(P=$ 0.384 and $P=0.09$ ).

The analysis of treatment-naïve primary tumors revealed that the avidity of ${ }^{68} \mathrm{Ga}-\mathrm{FAPI}(12.3 \pm 5.2)$ was significantly higher than that of ${ }^{18} \mathrm{~F}-\mathrm{FDG}(8.3 \pm 4.0)$ in signet-ring/mucinous carcinomas $(P=0.03)$ (Fig. 2). In addition, the uptake of ${ }^{68} \mathrm{Ga}-\mathrm{FAPI}$ was significantly lower than that of ${ }^{18} \mathrm{~F}-\mathrm{FDG}$ in poorly differentiated carcinomas (average $\mathrm{SUV}_{\max }, 12.7 \pm 3.7$ vs. $18.1 \pm 4.1 ; P=0.04$ ). There was no significant difference in the $\mathrm{SUV}_{\max }$ of primary lesions between ${ }^{68} \mathrm{Ga}$-FAPI and ${ }^{18} \mathrm{~F}$-FDG PET/CT among the welldifferentiated and moderately differentiated carcinomas $(P=0.08)$. Interestingly, in the neoadjuvant chemotherapy group, there was no significant difference in the $S_{U} V_{\text {max }}$ of primary lesions between ${ }^{68} \mathrm{Ga}$-FAPI and ${ }^{18} \mathrm{~F}-\mathrm{FDG} \mathrm{PET} / \mathrm{CT}$ among all carcinoma types $(P=0.09)$.

\section{Changes in TNM staging}

Compared to staging based on ${ }^{18} \mathrm{~F}-\mathrm{FDG} \mathrm{PET} / \mathrm{CT},{ }^{68} \mathrm{Ga}$-FAPI-PET/CT resulted in additional findings in 21 of the 37 patients, which led to changes in staging in a total of 9 patients. Specifically, 6 of the 18 treatment-naïve patients (31.6\%) were upstaged and 1 of the 18 treatment-naïve patients (5.6\%) were downstaged (Table 2). 
Table 2

Comparison of FDG PET-based and FAPI PET-based TNM staging of 37 CRC Patients

\begin{tabular}{|c|c|c|c|c|c|}
\hline \# & $\begin{array}{l}\text { Treatment } \\
\text { status }\end{array}$ & $\begin{array}{l}\text { TNM stage (FDG } \\
\text { PET based) }\end{array}$ & $\begin{array}{l}\text { TNM stage (FAPI } \\
\text { PET based) }\end{array}$ & Additional finding in FAPI-PET & $\begin{array}{l}\text { Change in } \\
\text { staging }\end{array}$ \\
\hline 1 & Post-operation & M1a & M1a & None & None \\
\hline 2 & $\begin{array}{l}\text { Treatment- } \\
\text { naive }\end{array}$ & T4aN2bM0 (『B) & T4aN2bM1a (『a) & Peritoneal metastasis & Upstage \\
\hline 3 & Post-operation & M1c & M1c & None & None \\
\hline 4 & $\begin{array}{l}\text { Treatment- } \\
\text { naive }\end{array}$ & T4aN2bM1c (『c) & 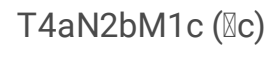 & $2 \mathrm{LNs}$ & None \\
\hline 5 & $\begin{array}{l}\text { Treatment- } \\
\text { naive }\end{array}$ & T1/2N0M1 (『a) & T1/2N0M0 (邓) & No rectal metastasis & Downstage \\
\hline 6 & $\begin{array}{l}\text { Treatment- } \\
\text { naive }\end{array}$ & T4aN2aM1c (『) & 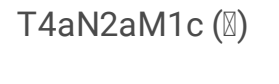 & $2 \mathrm{LNs}$ & None \\
\hline 7 & $\begin{array}{l}\text { Neoadjuvant } \\
\text { treatment }\end{array}$ & yT3N0M1a (『a) & yT3N0M1a (『a) & None & None \\
\hline 8 & $\begin{array}{l}\text { Neoadjuvant } \\
\text { treatment }\end{array}$ & yTONOMO & yTONOMO & None & None \\
\hline 9 & $\begin{array}{l}\text { Neoadjuvant } \\
\text { treatment }\end{array}$ & yTONOMO & yTONOMO & None & None \\
\hline 10 & $\begin{array}{l}\text { Neoadjuvant } \\
\text { treatment }\end{array}$ & yTON1aM0 & yTONOMO & None & None \\
\hline 11 & $\begin{array}{l}\text { Neoadjuvant } \\
\text { treatment }\end{array}$ & yTONOM1a (『a) & yTONOMO & No small intestinal metastasis & Downstage \\
\hline 12 & $\begin{array}{l}\text { Neoadjuvant } \\
\text { treatment }\end{array}$ & yTONOMO & yTONOMO & None & None \\
\hline 13 & $\begin{array}{l}\text { Neoadjuvant } \\
\text { treatment }\end{array}$ & yT4aNOM0 (『b) & yT4aNOM0 (『b) & None & None \\
\hline 14 & $\begin{array}{l}\text { Neoadjuvant } \\
\text { treatment }\end{array}$ & yTONOMO (0) & yTONOMO (0) & None & None \\
\hline 15 & $\begin{array}{l}\text { Treatment- } \\
\text { naive }\end{array}$ & T3N1bM1a (『a) & T3N1bM1a (『a) & $1 \mathrm{LN}$ & None \\
\hline 16 & $\begin{array}{l}\text { Treatment- } \\
\text { naive }\end{array}$ & 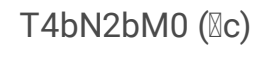 & 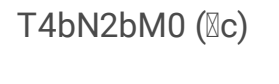 & $5 \mathrm{LNs}$ & None \\
\hline 17 & $\begin{array}{l}\text { Treatment- } \\
\text { naive }\end{array}$ & 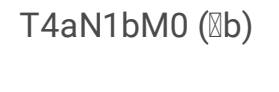 & T4aN1bM0 ( $₫ b)$ & $1 \mathrm{LN}$ & None \\
\hline 18 & $\begin{array}{l}\text { Treatment- } \\
\text { naive }\end{array}$ & T3N0M0 (『a) & T3N0M0 (『a) & None & None \\
\hline 19 & $\begin{array}{l}\text { Neoadjuvant } \\
\text { treatment }\end{array}$ & yTONOMO (0) & yTONOMO (0) & None & None \\
\hline 20 & $\begin{array}{l}\text { Treatment- } \\
\text { naive }\end{array}$ & T3N2aM1a (『a) & T3N2aM1a (『a) & $1 \mathrm{LN}$ & None \\
\hline 21 & $\begin{array}{l}\text { Treatment- } \\
\text { naive }\end{array}$ & 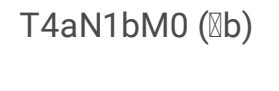 & T4aN1bM0 (『b) & $1 \mathrm{LN}$ & None \\
\hline 22 & $\begin{array}{l}\text { Treatment- } \\
\text { naive }\end{array}$ & T3N1bM0 (『b) & T3N1bM1c (『c) & $1 \mathrm{LN}+$ Peritoneal metastasis & Upstage \\
\hline
\end{tabular}




\begin{tabular}{|c|c|c|c|c|c|}
\hline \# & $\begin{array}{l}\text { Treatment } \\
\text { status }\end{array}$ & $\begin{array}{l}\text { TNM stage (FDG } \\
\text { PET based) }\end{array}$ & $\begin{array}{l}\text { TNM stage (FAPI } \\
\text { PET based) }\end{array}$ & Additional finding in FAPI-PET & $\begin{array}{l}\text { Change in } \\
\text { staging }\end{array}$ \\
\hline 23 & $\begin{array}{l}\text { Treatment- } \\
\text { naive }\end{array}$ & T3N1bM0 (『b) & T3N1bM0 (『b) & $1 \mathrm{LN}$ & None \\
\hline 24 & Post-operation & M1 & MO & $\begin{array}{l}\text { No metastatic recurrence in } \\
\text { anastomotic stoma }\end{array}$ & Downstage \\
\hline 25 & $\begin{array}{l}\text { Neoadjuvant } \\
\text { treatment }\end{array}$ & yT3N0M1a (『a) & yT3N0M1a (『a) & None & None \\
\hline 26 & $\begin{array}{l}\text { Treatment- } \\
\text { naive }\end{array}$ & T3N1bM0 (『) & T3N1bM0 (『) & $1 \mathrm{LN}$ & None \\
\hline 27 & $\begin{array}{l}\text { Treatment- } \\
\text { naive }\end{array}$ & T3NOMO (『) & T3N1aM0 (『b) & $1 \mathrm{LN}$ & Upstage \\
\hline 28 & $\begin{array}{l}\text { Treatment- } \\
\text { naive }\end{array}$ & T3N1cM0 (区) & T3N1cM1a (『a) & $1 \mathrm{LN}+$ Left acetabulum metastasis & Upstage \\
\hline 29 & Post-operation & M1c & M1c & None & None \\
\hline 30 & $\begin{array}{l}\text { Neoadjuvant } \\
\text { treatment }\end{array}$ & yT3N1aM0 (『b) & yT3N1bM0 (『b) & $1 \mathrm{LN}$ & None \\
\hline 31 & Post-operation & M1a & M1a & None & None \\
\hline 32 & $\begin{array}{l}\text { Neoadjuvant } \\
\text { treatment }\end{array}$ & yT3N2aM0 & yT3N2aM0 & None & None \\
\hline 33 & $\begin{array}{l}\text { Treatment- } \\
\text { naive }\end{array}$ & $\mathrm{T} 4 \mathrm{bN} 2 \mathrm{bM} 0(\mathbb{\nabla})$ & $\mathrm{T} 4 \mathrm{bN} 2 \mathrm{bM} 0(\mathbb{\nabla})$ & 2 LNs & None \\
\hline 34 & Post-operation & M1a & M1a & None & None \\
\hline 35 & $\begin{array}{l}\text { Treatment- } \\
\text { naive }\end{array}$ & T4aN1aM0 (『b) & T4aN2bM0 (『c) & 7 LNs & Upstage \\
\hline 36 & $\begin{array}{l}\text { Treatment- } \\
\text { naive }\end{array}$ & T4aN2aM0 (『) & T4aN2aM1a (『a) & 2 LNs + Liver metastasis & Upstage \\
\hline 37 & Post-operation & M1c & M1c & $\begin{array}{l}\text { No right axillary and internal } \\
\text { mammary LNs metastases }\end{array}$ & None \\
\hline
\end{tabular}

In all patients who were upstaged based on ${ }^{68} \mathrm{Ga}$-FAPI-PET/CT findings $(6 / 37,16.2 \%)$, the changes were based on the detection of new or additional distant metastases in one or more organ systems. All additional findings were confirmed by biopsy ( $9 / 21$, $42.9 \%)$ or other conventional imaging $(12 / 21,57.1 \%)$. Moreover, in 11 patients, new lymph node metastases were detected but did not change the stage (Table 2). The median ${ }^{68} \mathrm{Ga}$-FAPI uptake was higher than that of ${ }^{18} \mathrm{~F}$-FDG in both abdominal and pelvic lymph nodes (6.6 vs. 3.5, $P<0.001$, and 3.95 vs. $1.85, P<0.001$, respectively) (Fig. 3). However, the median ${ }^{68} \mathrm{Ga-FAPI}$ uptake was lower than that of ${ }^{18} \mathrm{~F}-\mathrm{FDG}$ in thoracic lymph nodes (2.0 vs. 3.2, $P=0.014$ ) (Table 3 ). 
Table 3

Comparison of ${ }^{18} \mathrm{~F}-\mathrm{FDG}$ and ${ }^{68} \mathrm{Ga}-\mathrm{FAPI}$ uptake in colorectal tumor sites

\begin{tabular}{|c|c|c|c|c|c|c|c|c|c|c|}
\hline & \multirow{2}{*}{$\begin{array}{l}\text { No. of } \\
\text { patients }\end{array}$} & \multicolumn{2}{|c|}{ Lesion size (cm) } & \multicolumn{2}{|c|}{${ }^{18}$ F-FDG PET/CT } & \multicolumn{4}{|c|}{${ }^{68} \mathrm{Ga}-\mathrm{FAPI}$ PET/CT } & \multirow{2}{*}{$\begin{array}{l}P \text { value } \\
\text { SUV }_{\text {max }} \\
\text { FDG vs. } \\
\text { SUV } \\
\text { FAPI } \\
\text { FAPI }\end{array}$} \\
\hline & & Median & Range & $\begin{array}{l}\text { Median } \\
\text { SUV }_{\text {max }}\end{array}$ & $\begin{array}{l}\text { SUV }_{\text {max }} \\
\text { range }\end{array}$ & $\begin{array}{l}\text { No. of } \\
\text { positive } \\
\text { lesions }\end{array}$ & $\begin{array}{l}\text { Median } \\
\text { SUV }_{\max }\end{array}$ & $\begin{array}{l}\text { SUV }_{\max } \\
\text { range }\end{array}$ & $\begin{array}{l}\text { No of } \\
\text { positive } \\
\text { lesions }\end{array}$ & \\
\hline Primary tumor & 18 & 1.3 & $\begin{array}{l}0.3- \\
2.7\end{array}$ & 13.1 & $\begin{array}{l}4.6- \\
25.7\end{array}$ & 19 & 12.7 & $\begin{array}{l}4.6- \\
25.5\end{array}$ & 19 & 0.384 \\
\hline \multicolumn{11}{|l|}{$\begin{array}{l}\text { Involved lymph } \\
\text { nodes }\end{array}$} \\
\hline $\begin{array}{l}\text { Cervical- } \\
\text { supraclavicular }\end{array}$ & 1 & NA & $\begin{array}{l}0.5- \\
0.7\end{array}$ & NA & $2.1-3.7$ & 2 & NA & $1.1-1.8$ & 1 & NA \\
\hline Thoracic $^{*}$ & 10 & 1.0 & $\begin{array}{l}0.7- \\
1.4\end{array}$ & 3.2 & $2.4-7.9$ & 17 & 2.0 & $\begin{array}{l}1.3- \\
12.9\end{array}$ & 13 & 0.014 \\
\hline Abdominal§ & 5 & 0.9 & $\begin{array}{l}0.4- \\
2.8\end{array}$ & 3.5 & $2.3-9.1$ & 20 & 6.6 & $\begin{array}{l}1.8- \\
20.5\end{array}$ & 34 & $<0.001$ \\
\hline Pelvic & 13 & 0.7 & $\begin{array}{l}0.3- \\
2.9\end{array}$ & 2.85 & $2.0-6.6$ & 56 & 3.95 & $\begin{array}{l}1.1- \\
17.6\end{array}$ & 84 & $<0.001$ \\
\hline \multicolumn{11}{|l|}{$\begin{array}{l}\text { Involved bone } \\
\text { and viscera }\end{array}$} \\
\hline Liver & 5 & 1.0 & $\begin{array}{l}0.7- \\
5.2\end{array}$ & 2.95 & $2.5-7.8$ & 5 & 2.6 & $1.7-5.0$ & 8 & 0.068 \\
\hline Lung & 4 & 0.8 & $\begin{array}{l}0.4- \\
1.5\end{array}$ & 1.5 & $0.5-9.2$ & 15 & 1.5 & $0.4-4.2$ & 12 & 0.414 \\
\hline Bone & 2 & NA & $\begin{array}{l}1.4- \\
3.1\end{array}$ & NA & $5.3-8.8$ & 2 & NA & 7.3-9.5 & 2 & NA \\
\hline Peritoneum & 10 & 0.9 & $\begin{array}{l}0.3- \\
9.0\end{array}$ & 2.6 & $\begin{array}{l}1.1- \\
10.5\end{array}$ & 17 & 3.7 & $\begin{array}{l}2.4- \\
12.6\end{array}$ & 23 & 0.016 \\
\hline \multicolumn{11}{|c|}{ * Lymph nodes in thoracic regions includes mediastinal or/and hilar, axillary and internal mammary lymph nodes } \\
\hline \multicolumn{11}{|c|}{ § Lymph nodes in abdominal regions includes paraaortic, retroperitoneal, and celiac lymph nodes } \\
\hline
\end{tabular}

Imaging with ${ }^{68} \mathrm{Ga}$-FAPI-PET/CT led to upstaging to stage IV based on the detection of peritoneal and bone metastases in two and one patient with newly diagnosed CRC, respectively (Table 2). In all 10 patients, the ${ }^{68} \mathrm{Ga}$-FAPI SUV $\max$ was higher than that of ${ }^{18} \mathrm{~F}$-FDG in peritoneal metastases (3.7 vs. 2.6, $P=0.01$ ) (Table 3). Compared with the ${ }^{18} \mathrm{~F}$-FDG PET/CT images, the peritoneal metastases were clearly visible in the ${ }^{68} \mathrm{Ga}$-FAPI PET/CT images (Fig. 4 and 5). There was no significant difference in the ${ }^{68} \mathrm{Ga}-$ FAPI and ${ }^{18} \mathrm{~F}$-FDG SUV $\max$ values in positive lung lesions $(P=0.414)($ Table 3$)$.

Although the ${ }^{68} \mathrm{Ga}-\mathrm{FAPI}$ and ${ }^{18} \mathrm{~F}-\mathrm{FDG}$ SUV $_{\text {max }}$ values did not significantly differ in positive liver lesions (median, 2.6 vs. $2.95, P=$ 0.07), the number of positive liver lesions detected by ${ }^{68} \mathrm{Ga}$-FAPI PET/CT was higher than that detected with ${ }^{18} \mathrm{~F}$-FDG PET/CT because of the lower background SUV $\mathrm{max}_{\text {of }}{ }^{68} \mathrm{Ga}$-FAPI. Eight positive liver lesions detected by ${ }^{68} \mathrm{Ga}$-FAPI PET/CT were confirmed as metastases by operation/biopsy and other imagines; only five of these positive liver lesions were detected by ${ }^{18} \mathrm{~F}-\mathrm{FDG}$ PET/CT $(62.5 \%, 5 / 8)$. The tumor/liver ratio of ${ }^{68} \mathrm{Ga}$-FAPI was significantly higher than that of ${ }^{18} \mathrm{~F}-\mathrm{FDG}(P=0.01)$, and the liver metastases 
were clearly visible in ${ }^{68} \mathrm{Ga}$-FAPI PET/CT images and finally demonstrated by MRI scan (Fig. 6). The detailed comparison of liver metastases detected with ${ }^{68} \mathrm{Ga}-\mathrm{FAPI}$ and ${ }^{18} \mathrm{~F}-\mathrm{FDG}$ PET/CT are presented in Table 4.

Table 4

Comparison of ${ }^{18} \mathrm{~F}$-FDG and ${ }^{68} \mathrm{Ga}-\mathrm{FAPI}$ uptake in liver metastases

\begin{tabular}{|c|c|c|c|}
\hline & $\begin{array}{l}{ }^{18} \mathrm{~F}-\mathrm{FDG} \\
\mathrm{PET} / \mathrm{CT}\end{array}$ & $\begin{array}{l}{ }^{68} \mathrm{Ga}-\mathrm{FAPI} \\
\mathrm{PET} / \mathrm{CT}\end{array}$ & $\begin{array}{l}P \text { value }\left(\mathrm{SUV}_{\max } \text { of }{ }^{18} \mathrm{~F}-\mathrm{FDG} \text { vs. } \mathrm{SUV}_{\max } \text { of }{ }^{68} \mathrm{Ga}-\right. \\
\text { FAPI) }\end{array}$ \\
\hline $\mathrm{SUV}_{\max }$ of liver lesion & $2.95(2.5-7.8)$ & $2.6(1.7-5.0)$ & 0.068 \\
\hline $\begin{array}{l}\text { Background SUV } \max \text { of } \\
\text { liver }\end{array}$ & $3.3(3.0-3.9)$ & $0.5(0.4-0.7)$ & 0.01 \\
\hline TBR & $0.89(0.6-2.4)$ & $6.5(4.2-7.1)$ & 0.012 \\
\hline
\end{tabular}

\section{Discussion}

In the present prospective study, we aimed to investigate the avidity of ${ }^{68} \mathrm{Ga}-\mathrm{FAPI}-04$ in CRC and to explore the potential utility of ${ }^{68} \mathrm{Ga}-\mathrm{FAPI} \mathrm{PET} / \mathrm{CT}$ as the sole imaging modality in primary and recurrent CRC. Our analyses indicated that ${ }^{68} \mathrm{Ga}-\mathrm{FAPI} \mathrm{PET} / \mathrm{CT}$ improved tumor staging in CRC patients because of favorable tumor/background activity and low tracer uptake in the gastrointestinal tract. Moreover, we found signet-ring/mucinous carcinomas accumulated more ${ }^{68} \mathrm{Ga}-\mathrm{FAPI}$ than ${ }^{18} \mathrm{~F}-\mathrm{FDG}$, while FAPI-avidity was lower than FDG-avidity in poorly differentiated carcinomas.

As key constituents of the tumor stroma, CAFs can support an immunosuppressive microenvironment, tumor cell growth, progression, and metastatic potential. Expressed by CAFs, FAP is an attractive diagnostic and therapeutic target $[8,10,17,18]$. ${ }^{68} \mathrm{Ga}-\mathrm{FAPI} \mathrm{PET} / \mathrm{CT}$ imaging is characterized by high tumor/background activity and is more sensitive than ${ }^{18} \mathrm{~F}-\mathrm{FDG} \mathrm{PET} / \mathrm{CT}$ in identifying primary gastrointestinal carcinoma lesions $[12,19]$.

The origin, number, and distribution of FAP-expressing CAFs as well as the number of FAP molecules per cell may differ among tumors. Mona et al. [20] reported the presence of a strong association between tumor ${ }^{68} \mathrm{Ga}$-FAPI uptake intensity and histopathological FAP expression in colon cancer. We expected variations in intratumoral tracer distribution in treatment-naïve patients with specific histopathologic types of CRC. In this study, we firstly demonstrated more FAP expression in signetring/mucinous carcinomas, which normal exhibited low ${ }^{18} \mathrm{~F}-\mathrm{FDG}$ uptake $[6,7,21,22]$. The finding revealed ${ }^{68} \mathrm{Ga}-\mathrm{FAPI}$ PET/CT would have the lower false negative rate in detecting primary and metastatic CRC lesions, comparing to ${ }^{18} \mathrm{~F}-\mathrm{FDG} \mathrm{PET} / \mathrm{CT}$. Interestingly, we also found that poorly differentiated carcinomas exhibited significantly lower ${ }^{68} \mathrm{Ga}-\mathrm{FAPI}$ uptake compared with ${ }^{18} \mathrm{~F}-\mathrm{FDG}$ even though this subtype were both ${ }^{68} \mathrm{Ga}-\mathrm{FAPI}$ - and ${ }^{18} \mathrm{~F}-\mathrm{FDG}$-avidity.

TNM classification provides the traditional and current guidelines to classify the extent of cancer spread. The degree of tumor progression and invasion at the time of surgical resection, as well as patient outcome, are estimated on the basis of this staging system for CRC. Our study demonstrated that ${ }^{68} \mathrm{Ga}$-FAPI-PET/CT was able to detect both primary tumors and metastases arising from CRC. The sensitivity was $100 \%$ with both ${ }^{68} \mathrm{Ga}$-FAPI and ${ }^{18} \mathrm{~F}-\mathrm{FDG}$ PET/CT and no significancy was found in SUV values in ${ }^{68} \mathrm{Ga}$-FAPI and ${ }^{18} \mathrm{~F}-\mathrm{FDG}$ PET/CT imagines. Furthermore, we found that FAPI and FDG uptakes in treatment-naïve lesions had no significant difference from those in posttreatment lesions. Thus, ${ }^{68} \mathrm{Ga}$-FAPI-PET/CT had a similar detecting efficiency to ${ }^{18} \mathrm{~F}-\mathrm{FDG}$ $\mathrm{PET} / \mathrm{CT}$ in T stage.

The superiority of ${ }^{18} \mathrm{~F}$-FDG PET/CT in CRC is evident in the detection of lymph nodes and distant metastases and the detection of additional metastases can significantly change treatment plans [23-25]. However, several studies showed that the detection of 
metastatic regional nodes was low/moderate using ${ }^{18} \mathrm{~F}-\mathrm{FDG}$ PET/CT, demonstrating the limitations of this method [26, 27]. Several studies suggest that CRC commonly harbor cancer-associated fibroblasts expressing fibroblast activation protein. Thus, this study had explored the reliability of ${ }^{68} \mathrm{Ga}$-FAPI-PET/CT in detection of metastatic CRC lesions. Our result revealed that ${ }^{68} \mathrm{Ga}$ FAPI PET/CT identified additional findings in 30 metastatic and 2 inflammatory lymph nodes from 17 patients with CRC, and improved $\mathrm{N}$ stage in CRC patients. In addition, the ${ }^{68} \mathrm{Ga}$-FAPI uptake was higher than the ${ }^{18} \mathrm{~F}$-FDG uptake in abdominal and pelvic involved lymph nodes, whereas thoracic FDG-avid inflammatory/age-related lymph nodes showed FAPI-negative.

According to $\mathrm{M}$ stage, early detection of isolated metastasis to the liver or other sites often improves survival following radical resection [28]. Because of the moderate FDG-uptake in liver, ${ }^{18} \mathrm{~F}$-FDG PET/CT was not the first choice for identifying the liver metastasis. Our data showed hepatic background was significantly lower when using ${ }^{68} \mathrm{Ga}-\mathrm{FAPI}$ compared to ${ }^{18} \mathrm{~F}-\mathrm{FDG}$, in according to the previous study. Thus, FAPI-imaging might be advantageous for patients with suspected liver metastases leading to a potential high detection rate. In the present study, the smallest diameter of the detected lesions was approximately $0.7 \mathrm{~cm}$. Peritoneum is another common site of CRC metastasis [29] and the degree of peritoneal metastasis also determines the choice of treatment $[24,30,31]$. The detection rate of peritoneal metastasis using ${ }^{18} \mathrm{~F}-\mathrm{FDG}$ PET/CT is not high, primarily due to intestinal inflammatory uptake, small lesions, and other factors including rare pathological types. ${ }^{68} \mathrm{Ga}$-FAPI is an active fibroblast-targeted imaging agent, and the development of peritoneal metastases is primarily due to active fibroblasts [29], supported by the significantly higher ${ }^{68} \mathrm{Ga}$-FAPI uptake in peritoneal metastatic lesions compared with ${ }^{18} \mathrm{~F}$-FDG observed in the present study.

In the present study, we also found that the ${ }^{68} \mathrm{Ga}$-FAPI uptake was significantly higher than that of ${ }^{18} \mathrm{~F}-\mathrm{FDG}$ in uterus, which might

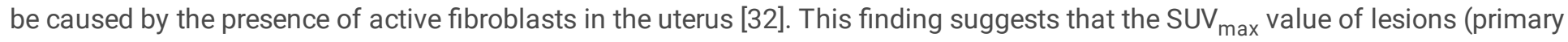
or/and metastases) located in the pelvic area might be affected by a high ${ }^{68} \mathrm{Ga}$-FAPI uptake, a potential shortcoming of ${ }^{68} \mathrm{Ga}-\mathrm{FAPI}$ $\mathrm{PET} / \mathrm{CT}$ imaging.

This study also has several limitations which should be acknowledged. The cohort size was small, and the number of patients with bone metastases was low. Future studies with larger cohorts are warranted to provide a more comprehensive analyses on the utility of ${ }^{68} \mathrm{Ga}-\mathrm{FAPI} \mathrm{PET} / \mathrm{CT}$ in CRC.

\section{Conclusion}

${ }^{68} \mathrm{Ga}-\mathrm{FAPI}$ PET/CT has several clear advantages over ${ }^{18} \mathrm{~F}-\mathrm{FDG}$ PET/CT, including the detection of lymph nodes and distant metastases, which improves the staging of patients with CRC. Additionally, patients might feel more comfortable during the ${ }^{68} \mathrm{Ga}-$ FAPI PET/CT scan because of no fasting.

\section{Declarations}

Acknowledgments The authors gratefully acknowledge all participating patients.

Funding This work was financially supported by the National Natural Science Foundation of China (no. 82071957, 82171980), Beijing Hospitals Authority Clinical Medicine Development of special funding support (code: XMLX202120).

Data availability The data used and/or analyzed during the current study area vailable from the corresponding author on reasonable request.

Ethics approval The study was approved by the Institutional Review Board of Beijing Cancer Hospital (no. 2019KT95) and registered in ClinicalTrials.gov (NCT04750772).

Consent to participate Patients provided written informed consent.

Consent to publish Patients signed informed consent regarding publishing their data and photographs.

Conflicts of interest The authors declare no potential conflicts of interest. 


\section{References}

1. Siegel RL, Miller KD, Jemal A. Cancer statistics, 2020. CA: A Cancer Journal for Clinicians. 2020;70:7-30. https://doi.org/10.3322/caac.21590.

2. Dekker E, Tanis PJ, Vleugels JLA, Kasi PM, Wallace MB. Colorectal cancer. Lancet. 2019;394:1467-80. https://doi.org/10.1016/S0140-6736(19)32319-0.

3. Chakedis J, Schmidt CR. Surgical Treatment of Metastatic Colorectal Cancer. Surg Oncol Clin N Am. 2018;27:377-99. https://doi.org/10.1016/j.soc.2017.11.010.

4. Kantorova I, Lipska L, Be O, Schneiderova M. Routine ${ }^{18}$ F-FDG PET Preoperative Staging of Colorectal Cancer: Comparison with Conventional Staging and Its Impact on Treatment Decision Making. J Nucl Med. 2003;44:1784-8. PMID: 14602860.

5. Petersen RK, Hess S, Alavi A, Høilund-Carlsen PF. Clinical impact of FDG-PET/CT on colorectal cancer staging and treatment strategy. Am J Nucl Med Mol Imaging. 2014;4:471-82. PMID: 25143865.

6. Berger KL, Nicholson SA, Dehdashti F, Siegel BA. FDG PET Evaluation of Mucinous Neoplasms: Correlation of FDG Uptake with Histopathologic Features. American Journal of Roentgenology. 2000;174:1005-8.

https://doi.org/10.2214/ajr.174.4.1741005.

7. Borello A, Russolillo N, Lo Tesoriere R, Langella S, Guerra M, Ferrero A. Diagnostic performance of the FDG-PET/CT in patients with resected mucinous colorectal liver metastases. The Surgeon. 2021;19:e140-5. https://doi.org/10.1016/j.surge.2020.09.004.

8. Lindner T, Loktev A, Altmann A, Giesel F, Kratochwil C, Debus J, et al. Development of Quinoline-Based Theranostic Ligands for the Targeting of Fibroblast Activation Protein. J Nucl Med. 2018;59:1415-22. https://doi.org/10.2967/jnumed.118.210443.

9. Chen H, Pang Y, Wu J, Zhao L, Hao B, Wu J, et al. Comparison of $\left[{ }^{68} \mathrm{Ga}\right] \mathrm{Ga}$-DOTA-FAPI-04 and $\left[{ }^{18} \mathrm{~F}\right]$ FDG PET/CT for the diagnosis of primary and metastatic lesions in patients with various types of cancer. Eur $\mathrm{J}$ Nucl Med Mol Imaging. 2020;47:1820-32. https://doi.org/10.1007/s00259-020-04769-z.

10. Loktev A, Lindner T, Burger E-M, Altmann A, Giesel F, Kratochwil C, et al. Development of Fibroblast Activation ProteinTargeted Radiotracers with Improved Tumor Retention. J Nucl Med. 2019;60:1421-9. https://doi.org/10.2967/jnumed.118.224469.

11. Chen $H$, Zhao $L$, Ruan D, Pang $Y$, Hao B, Dai Y, et al. Usefulness of $\left[{ }^{68} \mathrm{Ga}\right] \mathrm{Ga}$-DOTA-FAPI-04 PET/CT in patients presenting with inconclusive $\left[{ }^{18}\right.$ F]FDG PET/CT findings. Eur J Nucl Med Mol Imaging. 2021;48:73-86. https://doi.org/10.1007/s00259-02004940-6.

12. Koerber SA, Staudinger F, Kratochwil C, Adeberg S, Haefner MF, Ungerechts G, et al. The Role of ${ }^{68}$ Ga-FAPI PET/CT for Patients with Malignancies of the Lower Gastrointestinal Tract: First Clinical Experience. J Nucl Med. 2020;61:1331-6. https://doi.org/10.2967/jnumed.119.237016.

13. Pang Y, Zhao L, Luo Z, Hao B, Wu H, Lin Q, et al. Comparison of ${ }^{68} \mathrm{Ga}-F A P I$ and ${ }^{18} \mathrm{~F}$-FDG Uptake in Gastric, Duodenal, and Colorectal Cancers. Radiology. 2021;298:393-402. https://doi.org/10.1148/radiol.2020203275.

14. Jin X, Wei M, Wang S, Wang G, Lai Y, Shi Y, et al. Detecting fibroblast activation proteins in lymphoma using ${ }^{68} \mathrm{Ga}-\mathrm{FAPI}$ PET/CT. J Nucl Med. 2021. https://doi.org/ 10.2967/jnumed.121.262134.

15. Benson AB, Venook AP, Al-Hawary MM, Arain MA, Chen Y-J, Ciombor KK, et al. NCCN Guidelines Insights: Rectal Cancer, Version 6.2020: Featured Updates to the NCCN Guidelines. Journal of the National Comprehensive Cancer Network. National Comprehensive Cancer Network; 2020;18:806-15. https://doi.org/10.6004/jnccn.2020.0032.

16. Benson AB, Venook AP, Al-Hawary MM, Arain MA, Chen Y-J, Ciombor KK, et al. Colon Cancer, Version 2.2021, NCCN Clinical Practice Guidelines in Oncology. Journal of the National Comprehensive Cancer Network. National Comprehensive Cancer Network; 2021;19:329-59. https://doi.org/10.6004/jnccn.2021.0012.

17. Kratochwil C, Flechsig P, Lindner T, Abderrahim L, Altmann A, Mier W, et al. ${ }^{68}$ Ga-FAPI PET/CT: Tracer Uptake in 28 Different Kinds of Cancer. J Nucl Med. 2019;60:801-5. https://doi.org/10.2967/jnumed.119.227967. 
18. Lindner T, Loktev A, Giesel F, Kratochwil C, Altmann A, Haberkorn U. Targeting of activated fibroblasts for imaging and therapy. EJNMMI Radiopharm Chem. 2019;4:16. https://doi.org/10.1186/s41181-019-0069-0.

19. Pang Y, Zhao L, Luo Z, Hao B, Wu H, Lin Q, et al. Comparison of ${ }^{68} \mathrm{Ga}-F A P I$ and ${ }^{18} \mathrm{~F}$-FDG Uptake in Gastric, Duodenal, and Colorectal Cancers. Radiology. 2021;298:393-402. https://doi.org/10.1148/radiol.2020203275.

20. Mona CE, Benz MR, Hikmat F, Grogan TR, Lückerath K, Razmaria A, et al. Correlation of ${ }^{68} \mathrm{Ga}$-FAPi-46 PET biodistribution with FAP expression by immunohistochemistry in patients with solid cancers: a prospective translational exploratory study. J Nucl Med. 2021. https://doi.org/10.2967/jnumed.121.262426.

21. Huang S, Sun C, Li X, Guan J, Feng S, Peng Z, et al. [Comprehensive application of CT and PET/CT in diagnosing colorectal mucinous and non-mucinous adenocarcinoma]. Zhonghua Wei Chang Wai Ke Za Zhi. 2014;17:230-4. PMID: 24671809.

22. Barbaro B, Leccisotti L, Vecchio FM, Di Matteo M, Serra T, Salsano M, et al. The potential predictive value of MRI and PET-CT in mucinous and nonmucinous rectal cancer to identify patients at high risk of metastatic disease. Br J Radiol. 2017;90:20150836. https://doi.org/10.1259/bjr.20150836.

23. Yang Z, Liu Z. The efficacy of ${ }^{18} \mathrm{~F}$-FDG PET/CT-based diagnostic model in the diagnosis of colorectal cancer regional lymph node metastasis. Saudi Journal of Biological Sciences. 2020;27:805-11. https://doi.org/ 10.1016/j.sjbs.2019.12.017.

24. Elekonawo FMK, Starremans B, Laurens ST, Bremers AJA, de Wilt JHW, Heijmen L, et al. Can [ ${ }^{18}$ F]F-FDG PET/CT be used to assess the pre-operative extent of peritoneal carcinomatosis in patients with colorectal cancer? Abdom Radiol. 2020;45:3016. https://doi.org/10.1007/s00261-019-02268-w.

25. Laurens ST, Oyen WJG. Impact of Fluorodeoxyglucose PET/Computed Tomography on the Management of Patients with Colorectal Cancer. PET Clinics. 2015;10:345-60. https://doi.org/10.1016/j.cpet.2015.03.007.

26. Tsunoda Y, Ito M, Fujii H, Kuwano H, Saito N. Preoperative diagnosis of lymph node metastases of colorectal cancer by FDGPET/CT. Jpn J Clin Oncol. 2008;38:347-53. https://doi.org/10.1093/jjco/hyn032.

27. Chen R, Wang Y, Zhou X, Huang G, Liu J. Preoperative PET/CT ${ }^{18}$ F-FDG Standardized Uptake by Lymph Nodes as a Significant Prognostic Factor in Patients with Colorectal Cancer. Contrast Media \& Molecular Imaging. 2018;2018:1-7. https://doi.org/10.1155/2018/5802109.

28. Daza JF, Solis NM, Parpia S, Gallinger S, Moulton C-A, Belley-Cote EP, et al. A meta-analysis exploring the role of PET and PETCT in the management of potentially resectable colorectal cancer liver metastases. Eur J Surg Oncol. 2019;45:1341-8. https://doi.org/10.1016/j.ejso.2019.03.025.

29. Koumpa FS, Xylas D, Konopka M, Galea D, Veselkov K, Antoniou A, et al. Colorectal Peritoneal Metastases: A Systematic Review of Current and Emerging Trends in Clinical and Translational Research. Gastroenterol Res Pract. 2019;2019:5180895. https://doi.org/10.1155/2019/5180895.

30. Chouillard E, Greco V, Tsiminikakis N. Peritoneal carcinomatosis of colorectal origin: is it really an end-stage disease? Tech Coloproctol. 2013;17:619-21. https://doi.org/10.1007/s10151-013-1063-2.

31. De Gaetano AM, Calcagni ML, Rufini V, Valenza V, Giordano A, Bonomo L. Imaging of peritoneal carcinomatosis with FDG PET-CT: diagnostic patterns, case examples and pitfalls. Abdom Imaging. 2009;34:391-402. https://doi.org/10.1007/s00261-008-9405-7.

32. Karpathiou G, Chauleur C, Dridi M, Baillard P, Corsini T, Dumollard JM, et al. Histologic Findings of Uterine Niches. Am J Clin Pathol. 2020;154:645-55. https://doi.org/10.1093/ajcp/aqaa080.

\section{Figures}




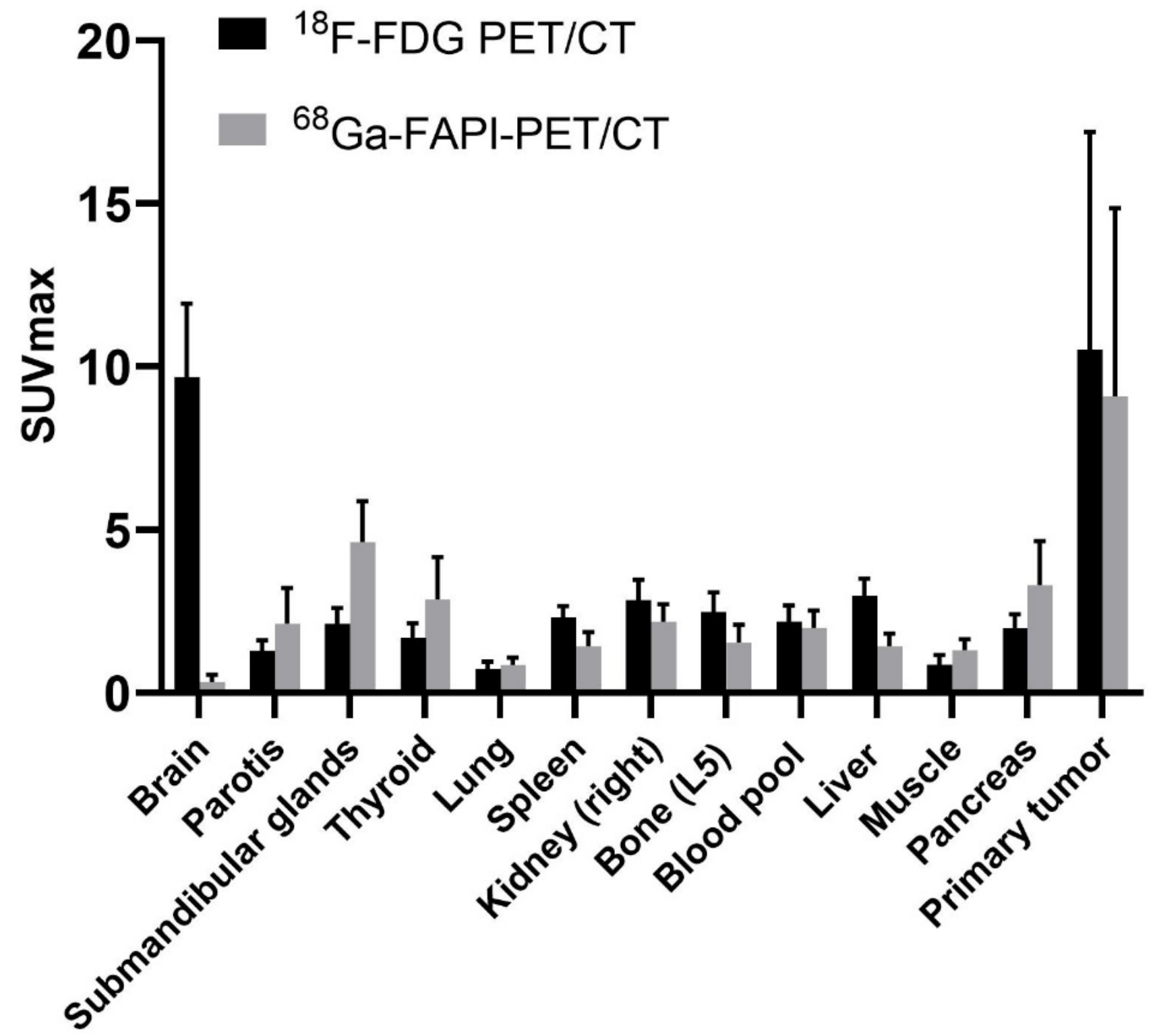

Figure 1

PET-based biodistribution analysis of 37 patients evaluated with ${ }^{68} \mathrm{Ga}-\mathrm{FAPI} P E T / C T$ and ${ }^{18} \mathrm{~F}-\mathrm{FDG}$ PET/CT one hour after the injection of the tracer 

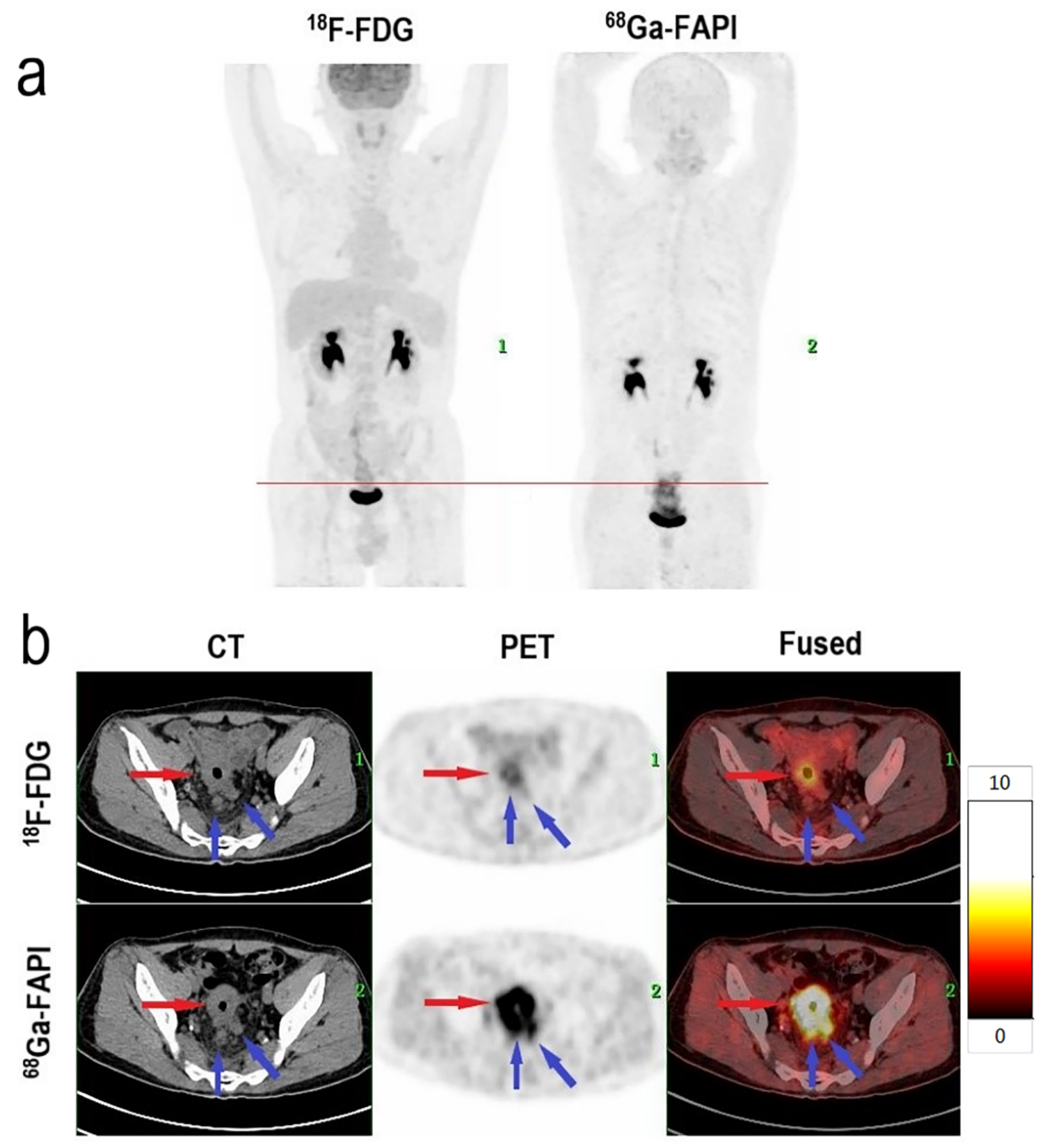

Figure 2

Staging of a patient with rectal mucinous carcinoma. (a) Mean intensity projection images of ${ }^{18} \mathrm{~F}-\mathrm{FDG}$ and ${ }^{68} \mathrm{Ga}$-FAPI PET/CT scans. (b) Axial CT, PET, and fused images at the level of primary lesion (red line in a) and two metastatic lymph nodes (blue line in a) are shown. In contrast to ${ }^{18} \mathrm{~F}$-FDG PET/CT, ${ }^{68} \mathrm{Ga}$-FAPI PET/CT allowed the discrimination of the primary lesion (red arrows) and lymph nodes metastases (blue arrows) due to the higher uptake of tracer 


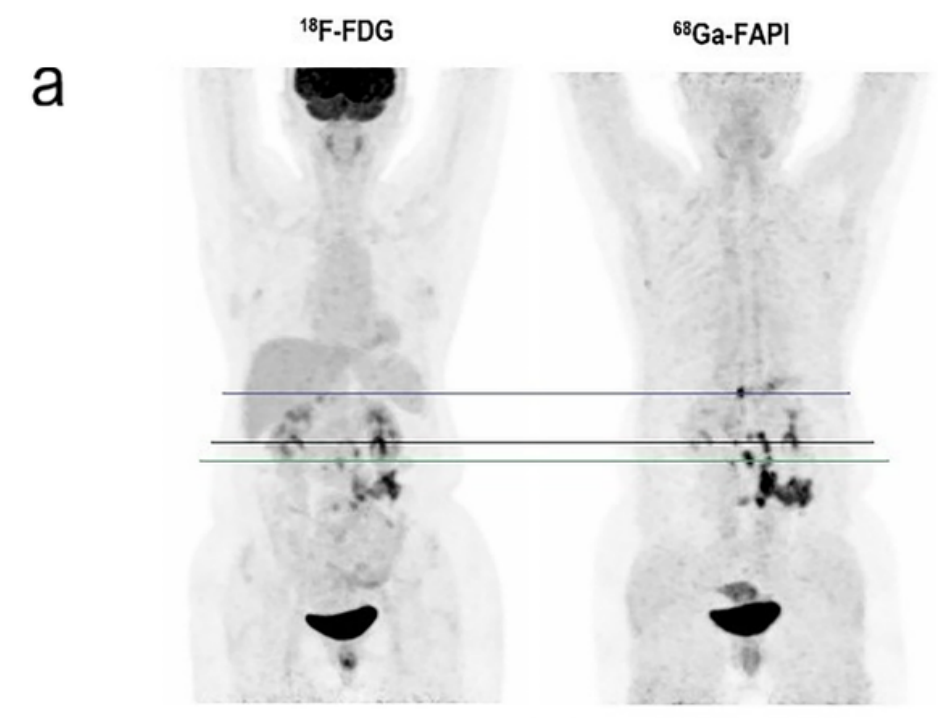

b

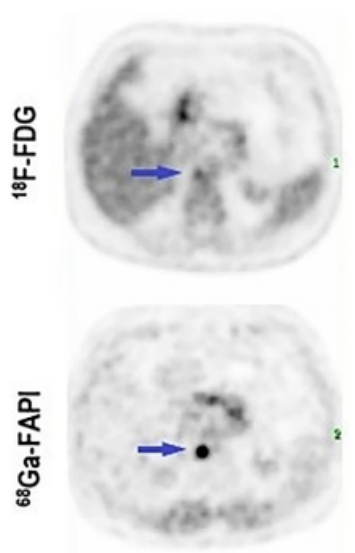

Fused

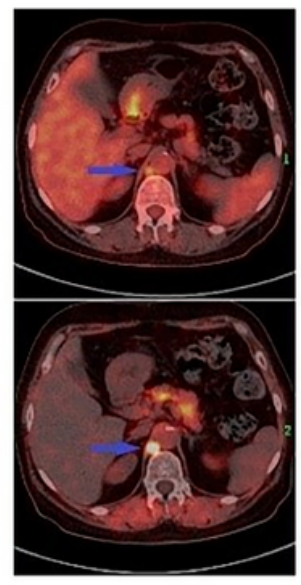

PET

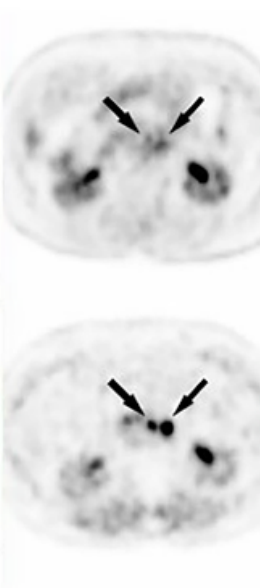

PET

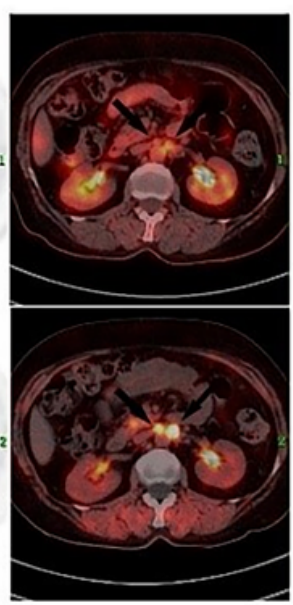

Fused

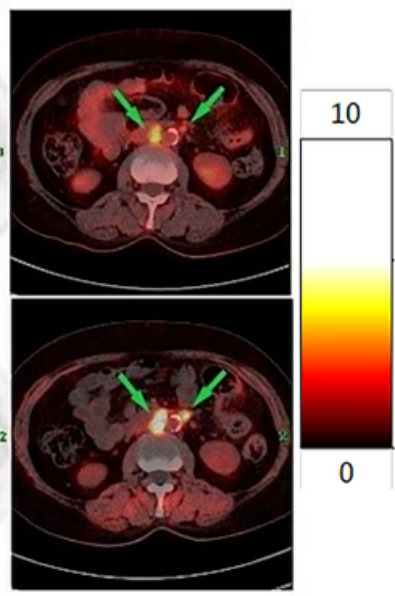

Figure 3

Staging of a patient with colon cancer and metastatic lymph nodes. (a) Mean intensity projection images of ${ }^{18} \mathrm{~F}-\mathrm{FDG}$ and ${ }^{68} \mathrm{Ga}$ FAPI PET/CT scans. (b) Axial CT, PET, and fused images at different levels of metastatic lymph nodes (blue, black, and green lines in a) are shown. The uptake of ${ }^{68} \mathrm{Ga}-\mathrm{FAPI}$ is higher in both the diaphragmatic (blue arrows) and retroperitoneal (black and green arrows) metastatic lymph nodes compared to that of ${ }^{18} \mathrm{~F}-\mathrm{FDG}$ 

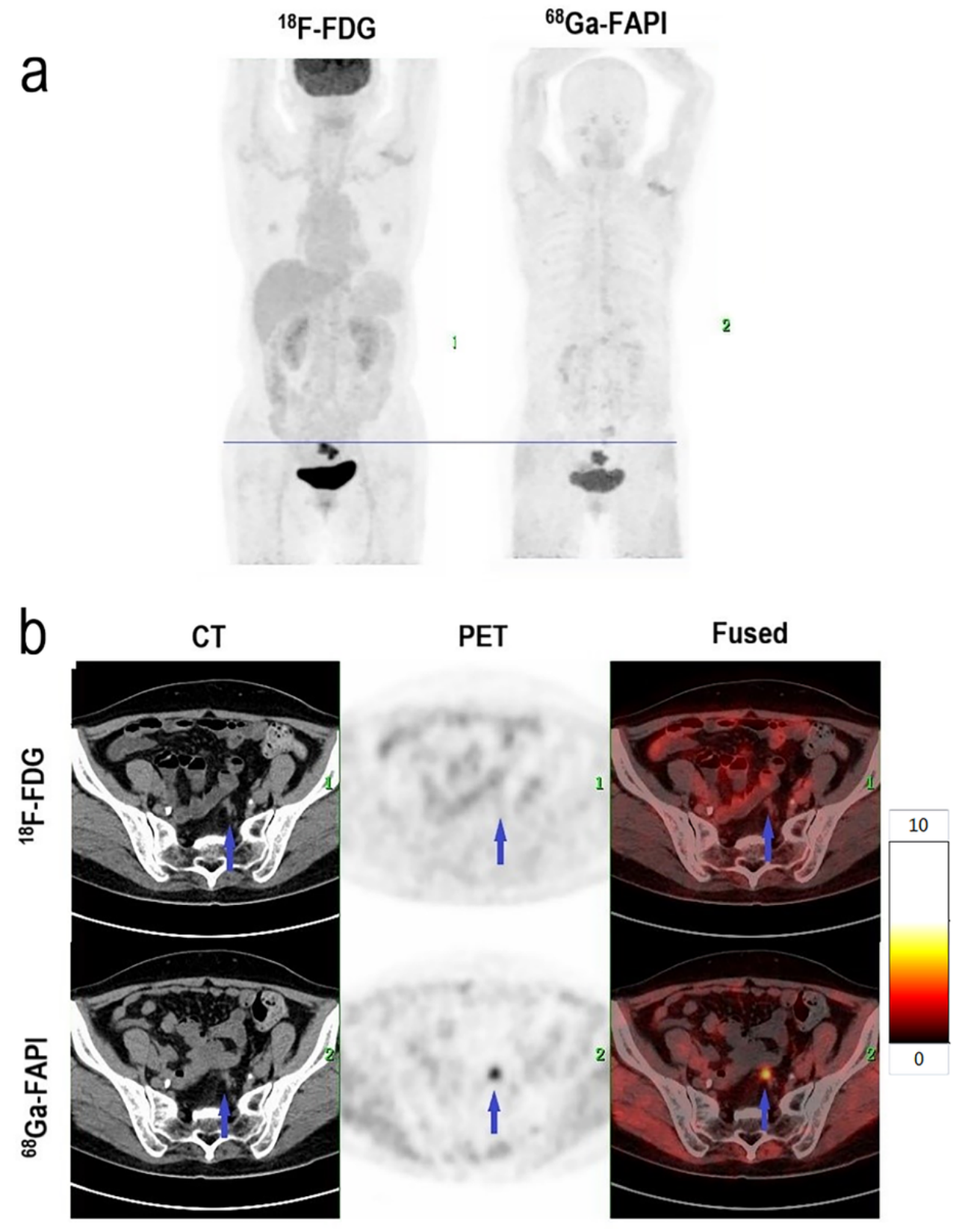

Figure 4

A patient with rectal cancer and peritoneal metastasis. (a) Mean intensity projection images of ${ }^{18} \mathrm{~F}-\mathrm{FDG}$ and ${ }^{68} \mathrm{Ga}$-FAPI PET/CT scans. (b) Axial CT, PET, and fused images at the level of liver metastasis (blue line in a) are shown. Pelvic perineal carcinoma is distinctly observed in the ${ }^{68} \mathrm{Ga}$-FAPI PET/CT scans because of the high tracer uptake compared with the ${ }^{18} \mathrm{~F}$-FDG PET/CT scans 

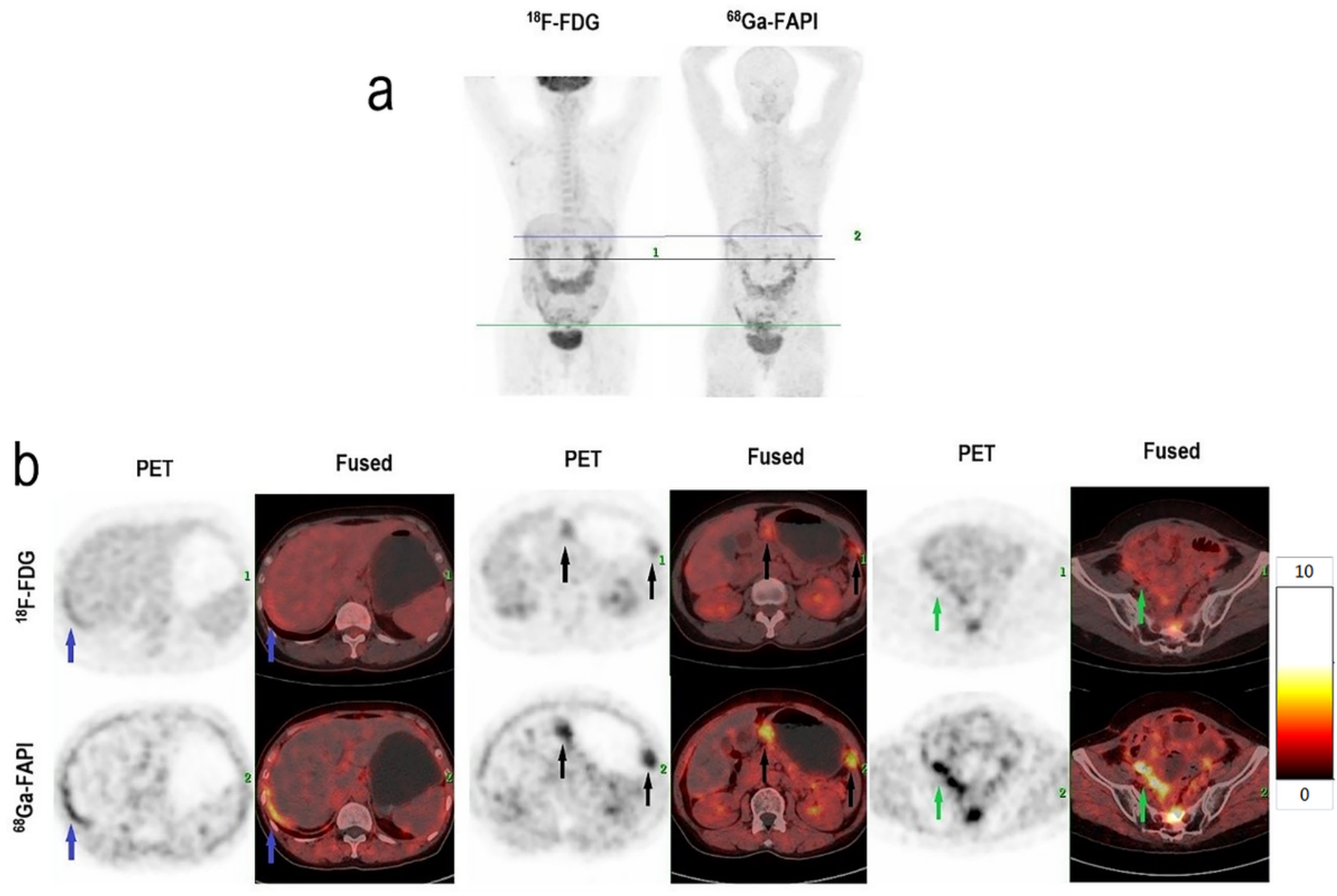

\section{Figure 5}

Staging of a patient with colon cancer and with metastatic perineal carcinoma. (a) Mean intensity projection images of ${ }^{18} \mathrm{~F}-\mathrm{FDG}$ and ${ }^{68} \mathrm{Ga}$-FAPI PET/CT scans. (b) Axial CT, PET, and fused images at different levels of metastatic peritoneal lesions (blue, black, and green lines in a) are shown. The ${ }^{68} \mathrm{Ga}$-FAPI uptake is higher than that of ${ }^{18} \mathrm{~F}$-FDG in perineal carcinomas 
a

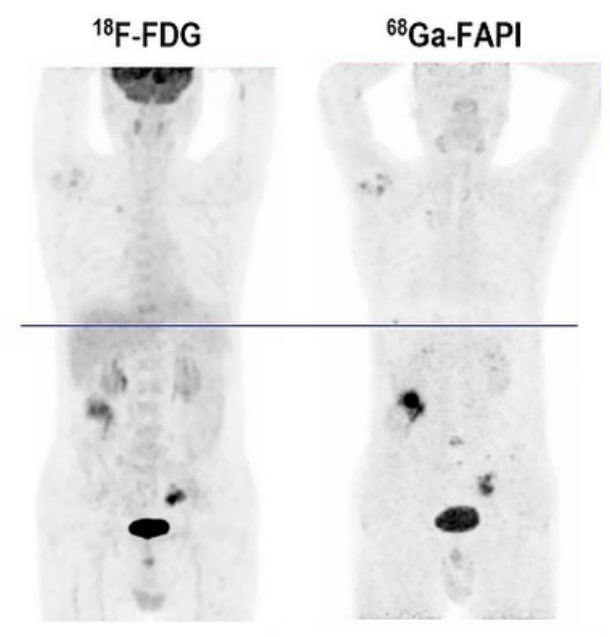

b

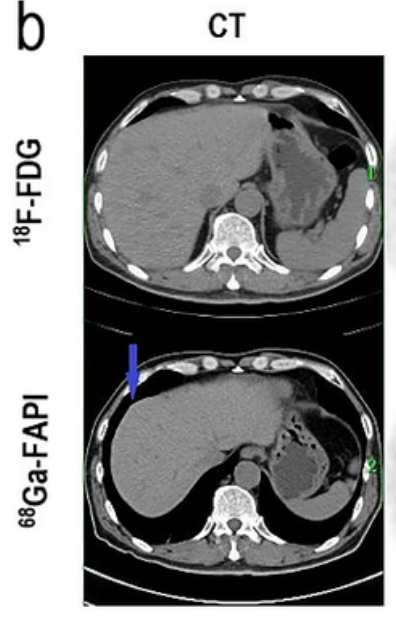

PET

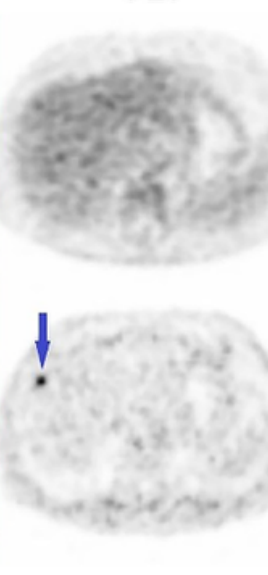

Fused

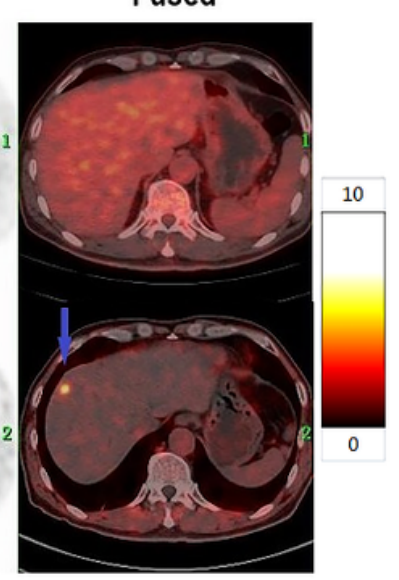

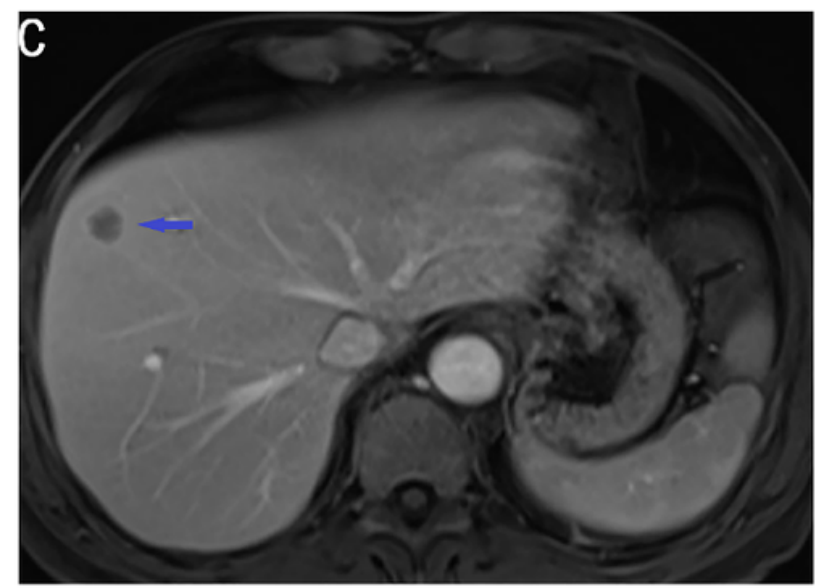

d

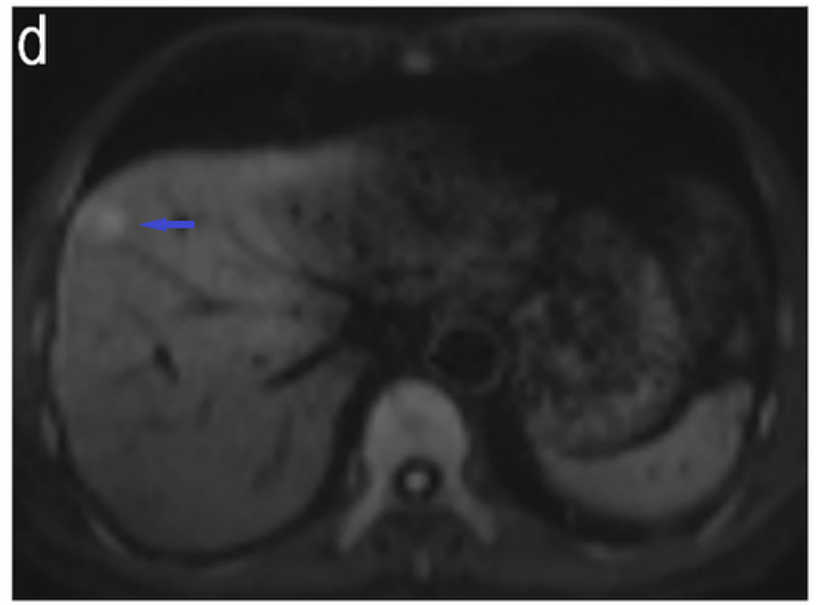

\section{Figure 6}

A patient with colon cancer that has metastasized to the liver. (a) Mean intensity projection images of ${ }^{18} \mathrm{~F}-\mathrm{FDG}$ and ${ }^{68} \mathrm{Ga}-\mathrm{FAPI}$ PET/CT scans. (b) Axial CT, PET, and fused images at level of liver metastasis (blue line in a) are shown. (c and d) Images of enhanced MRI scan, $\mathrm{T}_{2} \mathrm{WI}$ (delay phase) and DWI. The metastatic lesion in the right liver lobe is clearly revealed in ${ }^{68} \mathrm{Ga}-\mathrm{FAPI}$ $\mathrm{PET} / \mathrm{CT}$ images (blue arrows) but is absent in ${ }^{18} \mathrm{~F}-\mathrm{FDG}$ PET/CT images, which was confirmed by enhanced MRI scan and was clearly shown (blue arrows)

\section{Supplementary Files}

This is a list of supplementary files associated with this preprint. Click to download.

- ESM1.docx 